\title{
Managing the Attractiveness of Evolved and Created Retail Agglomeration Formats
}

\begin{abstract}
Purpose: This paper identifies those attributes of created and evolved retail agglomeration formats that have a substantial impact on overall attractiveness from the consumers' point of view. From an agglomeration management perspective primary areas of concern are identified and suggestions to increase the competitiveness of diverse agglomeration formats are presented.
\end{abstract}

Design/methodology: Through synthesizing pertinent literatures we produce a conceptual framework that proposes significant impacts between ten generic agglomeration attributes and different dimensions of attractiveness. We then test the hypotheses using a survey of more than 1,000 consumers of three competing agglomeration formats (a town center, a strip center and a regional shopping mall) in a particular locality.

Findings: Retail related factors and the atmosphere influence attractiveness most significantly in each of the three settings. All other factors - in particular convenience related ones - show only format specific relevance or are of no direct importance on the consumers' evaluation of attractiveness.

Research limitations/implications: The findings can only be transferred to similar retail settings and do not consider supra-regional agglomerations.

Practical implications: The results suggest that management of all three agglomerations is quite limited in directly influencing attractiveness. They should instead focus on the optimum selection of retail tenants and support or compliment the marketing endeavors of their tenants.

Originality/value: The focus is on regional retail agglomerations and considers the interdependencies between different formats in one geographical area. The in-vivo survey approach takes into account the moderating effect of the shopping situation when consumers' evaluate the attractiveness of competing shopping venues.

Keywords: Shopping center, town center, retail location, attractiveness, consumer patronage

Classification: Research Paper 


\section{Introduction}

Retail agglomerations can be defined as a cluster of stores within a clearly defined spatial area. Despite the heterogeneity of agglomeration formats they are often characterized as being either the product of an explicitly planned process or are considered to have emerged incrementally over time (Teller, 2008). The former "created" retail agglomerations include shopping malls, galleries, strip centers or factory outlets; whereas the latter "evolved" retail agglomerations encompass town centers, shopping strips or high/shopping streets, retail parks, and the like (Berman and Evans, 2009). The number of purpose built, and effectively managed, created retail agglomerations have been on the rise in recent years - and, therefore, both intra and intercompetition between formats has become progressively fierce (e.g., Guy, 2007). Accordingly, an understanding of why some formats or specific agglomerations are more 'preferable' or 'attractive' to both tenants and consumers, and how agglomeration management (e.g. town center and shopping center managers, as well as others involved in place marketing and management activities) can influence the attractiveness of their store clusters has become of increasing interest.

In generic terms this clustering of stores compared to solitary store locations is favored by both consumers and tenants. Consumers are often attracted to agglomerations since they offer a greater selection of products in one place and the shopping experiences can be facilitated and enriched overall by infrastructural facilities (e.g., public washrooms or recreational areas), as well as non retail related offerings (i.e., bars, eateries, cinemas) - see, Teller et al. (2008). For retailers, they organically produce "agglomeration effects" (Oppewal and Holyoake, 2004); synergies resulting from the location of other stores nearby (Schnedlitz and Teller, 2008). Furthermore, tenants can benefit from the same infrastructure (e.g. road networks or parking facilities) and the overall stream of consumers that they themselves did not necessarily generate (Ingene, 1984). Such effects are manifest in characteristics of retail agglomerations - such as accessibility, the tenant mix or the overall atmosphere - that are perceived by consumers as attributes and can be influenced by the agglomeration and/or the tenant management (Finn and Louviere, 1996). As a result store 
locations embedded in agglomerations are preferred by retailers across different retail sectors and, therefore, the volume of sales generated in retail agglomerations compared to those in solitary locations is increasing. Consequently an appreciation of the factors that underpin consumers' preferences for inhabiting different agglomeration formats rather than single stores has become increasingly important for retailers as well as other tenants of retail agglomerations to enable and facilitate commercial success.

In terms of agglomeration research most contributions focus on the characteristics of created and/or supra-regional agglomerations - most noticeably shopping malls - investigated in terms of their impact on their preferability or consumer patronage behavior (Cf. Teller, 2008). Specifically regional, as well as smaller, agglomeration formats have been relatively neglected in the extant literature. Given the saliency of both evolved formats in general and regional agglomerations in particular within the fabric of the urban retail landscape (Wrigley and Lowe, 2002), and their importance in satisfying different consumers' wants and needs in particular localities, they warrant further investigation (Warnaby et al., 2005). Indeed only very few authors have examined more than one agglomeration and consider the interdependencies between different agglomerations, including evolved formats. Consequently this paper focuses on the generic, i.e. format independent, agglomeration attributes that affect the overall attractiveness of retail agglomerations and identify those distinct areas of concern that need to be targeted by managers in order to increase the competitiveness of their specific format.

The paper is structured as followed: after these introductory remarks, we identify attributes of retail agglomerations that are proposed to affect all dimensions of agglomeration attractiveness or consumer patronage in the extant literature. Based on this review, we then develop a conceptual model that is subsequently tested in three competing retail agglomerations, each representing different small formats in the same study site. After a characterization of the sample, the results are described and discussed with respect to the identified literature. A limitations and outlook section concludes the paper. 


\section{Generic Attributes and the Attractiveness of Retail Agglomerations}

Different agglomeration formats in general and each retail agglomeration in particular are characterized by very specific attributes that are perceived to be relevant for consumers. Given the shopping task - together with the preferences and experiences of consumers - such attributes are proposed to have an effect on the evaluated attractiveness and consequently the patronage behavior of retail agglomerations within the relevant (choice) set of consumers (Finn and Louviere, 1996). Attractiveness in this context can be understood as a multi-faceted construct operationalized by at least three dimensions (Teller and Reutterer, 2008; Anselmsson, 2006): satisfaction with the agglomeration, retention proneness at the agglomeration and patronage intention towards the agglomeration. Each of these three dimensions are strongly interlinked and underscore the importance for agglomeration managers to meet their consumers' needs and wants in order to make them stay and to return in the future. Consequently, the attractiveness of an agglomeration is related to the share of spending, share of time and share of choice/visits of consumers relative to that of the competition.

The following agglomeration attributes have been discussed in literature focusing on agglomeration patronage as an influence on the attractiveness of agglomerations from the consumers' point of view. It is worth mentioning that following review takes into account the similarities of agglomeration formats and but neglects very specific attributes of certain formats e.g. information counters in shopping malls.

Accessibility: This factor accounts for the evaluation of the convenience regarding overcoming the distance between the points of origin - e.g. household, workplace - and the agglomeration. It encompasses not only spatial and temporal dimensions concerning to how easy and how quickly the destination can be reached but also considers perceived obstacles on the way, such as traffic jams, travel frequencies of trains/buses and road works (Ingene, 1984). This factor has been seen as crucial for different dimensions of store - but also agglomeration - attractiveness 
and actual choice behavior (see e.g. Ruiz et. al., 2004; Reimers and Clulow, 2004; Leo and Philippe, 2002; Arentze and Timmermans, 2001; Bearden, 1977; Bellenger et al., 1977).

Parking conditions: Agglomerations have become preferred shopping destinations for multipurpose shopping trips with automobiles being used as the preferred means of transport (e.g. Bacon, 1995). The availability of free parking spaces and the type of parking facilities offered at agglomerations at the time of the shopping trip is thus an integrative part of perceived accessibility of a retail location (Leo and Philippe, 2002; Tang et al., 2001; Van der Waerden et al., 1998). The convenience of overcoming the distance between the parking spaces and the agglomeration, and consequently the tenants, can be seen as the last step to enter the shopping destination and therefore is an important dimension of attractiveness (Bearden, 1977; Bellenger et al., 1977).

Tenant mix: The composition, the number and type of retail and non retail tenants - i.e. bars, eateries, entertainment facilities - within agglomerations represent the range of possibilities to satisfy consumers' wants and needs as well as minimizing the logistics of the shopping endeavor (see e.g., Teller and Reutterer, 2008; Leo and Philippe, 2002; Dellaert et al., 1998; Wakefield and Baker, 1998). According to Nelson (1958) a mix of tenants generates a "cumulative attraction" of a retail location for consumers. The latter refers to the role of retail stores as the organic source of an agglomeration's attractiveness.

Product range, merchandise value and sales personnel: The next three factors characterize the retail offer of an agglomeration. This includes the product range offered in terms of the width and breadth of assortments of the retail stores and the merchandise value in terms of the price-value ratio of merchandise, the overall price level and the number of price promotions available (see e.g., Leo and Philippe, 2002; Baker et al., 2002; Van Kenhove et al., 1999; Bearden, 1977; Bellenger et al., 1977). The final factor to be included is the characteristics of the sales personnel in terms of friendliness, competency and supportiveness (e.g., Anselmsson, 2006; Ruiz et al., 2004). These factors are strongly related to the retail tenant mix and are seen as antecedents of both the 
attractiveness of the retail stores in general (Woodside and Trappey, 1992) and, consequently, the attractiveness of an agglomeration.

Atmosphere: Consumers in a retail agglomeration are confronted with a set of visual, olfactory, tactile, auditory stimuli that are either actively or passively used by the retail and agglomeration management (Michon et al., 2005; Hoffman and Turley, 2002). Consumers perceive this stimulus set as an atmosphere which is proposed to have an effect on the evaluation of the attractiveness of the agglomeration and therefore their shopping behavior. Apart from the overall perception of the atmosphere stimuli - including, for example, odor, air, temperature, light, cleanliness - architecture and mood are frequently mentioned stimuli in literature taking into account the limited capability of managers of evolved agglomerations formats in sending out stimuli such as music or video messages on screens (see e.g. Baker et al., 2002; Ruiz et al., 2004; Bellenger et al., 1977).

Orientation and infrastructural facilities: This factor accounts for the convenience relating to searching, locating and accessing stores or other tenants within an agglomeration. It is influenced by the arrangement of tenants as well as the ease of orientation within the retail location. Furthermore, the pace and number of obstacles that inhibit consumers' access to tenants need to be taken into consideration (Ingene, 1984). A related factor is the infrastructural facilities offered to consumers (Baker et al., 2002). This includes the availability of ATMs, washrooms and recreational areas (Bellenger et al., 1977). As with parking conditions these factors contribute to the convenience of the shopping trip within the premises of an agglomeration and are, therefore, seen to influence the evaluation of attractiveness of the agglomeration in its totality (Reimers and Clulow, 2009).

\section{Managing attributes of different formats}

The generic tasks of an agglomeration management are to (1) identify and select the optimum mix of retail and non retail tenants; (2) manage and maximize the utilization of space within an agglomeration; (3) market or promote the agglomeration as a shopping destination; (4) 
coordinate infrastructural and common tasks (e.g., custody, cleaning, maintenance of exterior facilities); and, (5) facilitate footfall and the movement of stationary traffic (Schnedlitz and Teller, 2008). In other words a major task of management is to influence the attributes of an agglomeration in favor of customers and tenants. These tasks, however, vary across different formats - this is particularly the case for evolved as against created agglomerations (Teller, 2008). The reason for that is that created agglomerations are planned, constructed and managed according to the requirements of retailers and other tenants located there. Evolved agglomerations often lack this centralized management; they are not exclusively built for commercial purposes and the requirements of consumers who inhabit the agglomeration (e.g. Berman and Evans, 2009). Other interest groups including residents, tourists or visitors need also be taken into consideration within an overall (urban) place management concept. Nonetheless, the management of evolved clusters lack the contract based authority of shopping center management and thus is often dependent on the good-will of tenants to cooperate (Howard, 1997). Table 1 contrasts the challenges agglomeration management face when attempting to influence agglomeration attributes.

The influence and capability of the agglomeration management is comparably limited in evolved agglomerations - and cannot react to changes in the agglomeration related environment or competition as quickly and substantially as created formats (Teller, 2008). Nonetheless, urban place marketing and management initiatives in some European countries try to imitate professional shopping center management practices. The ultimate aim is to increase the declining competitiveness of urban evolved retail agglomerations against their mostly peripheral and increasingly powerful created counterparts (Warnaby et al., 2005; Warnaby and Medway, 2004). As a consequence it is important for agglomeration management of evolved retail agglomerations, as it is for the management of created formats, to focus on the drivers of attractiveness of the managed place and as such its competitors. This ultimately reveals those management and marketing areas that need to be concentrated on the most to increase the preferences and loyalty of both consumers and tenants alike. 


\section{Table 1: Format specific circumstances for managing agglomeration attributes}

\begin{tabular}{|c|c|c|}
\hline \multirow[b]{2}{*}{ Agglomeration attributes } & \multicolumn{2}{|c|}{ Agglomeration format group } \\
\hline & Evolved agglomeration formats & Created agglomeration formats \\
\hline \multirow[t]{2}{*}{ Accessibility } & Difficult to influence & Considered when planned \\
\hline & Dependent on the local authorities & Influenced by the management \\
\hline \multirow{3}{*}{$\begin{array}{l}\text { Parking conditions } \\
\text { (number and type of } \\
\text { parking lots, parking } \\
\text { fees, accessibility from } \\
\text { parking lots) }\end{array}$} & $\begin{array}{l}\text { Dependent on the given building structure, } \\
\text { local authorities and other stakeholder } \\
\text { groups of the place }\end{array}$ & $\begin{array}{l}\text { Number, type and location of parking spaces } \\
\text { considered in a planning stage }\end{array}$ \\
\hline & $\begin{array}{l}\text { Number of spaces usually limited or hard to } \\
\text { extend }\end{array}$ & $\begin{array}{l}\text { Flexible in changing the parking } \\
\text { infrastructure }\end{array}$ \\
\hline & $\begin{array}{l}\text { Facilities administered by or on behalf of } \\
\text { local authorities (parking fees and control) }\end{array}$ & $\begin{array}{l}\text { Administered and controlled by or on behalf } \\
\text { of the management. }\end{array}$ \\
\hline $\begin{array}{l}\text { Tenant mix } \\
\text { (retail and non retail } \\
\text { offer) }\end{array}$ & $\begin{array}{l}\text { Organically grown } \\
\text { Only influenceable indirectly by offering } \\
\text { incentives to both the landlords and the } \\
\text { (prospective) tenants }\end{array}$ & $\begin{array}{l}\text { Planned and directly influenceable (lease } \\
\text { contracts between the tenants and the estate } \\
\text { owner, represented by the management) }\end{array}$ \\
\hline $\begin{array}{l}\text { Atmosphere } \\
\text { (atmospheric stimuli) }\end{array}$ & $\begin{array}{l}\text { Stimuli naturally evolve, } \\
\text { Only indirectly influenceable and } \\
\text { consistently manageable based on the good- } \\
\text { will of the tenants }\end{array}$ & $\begin{array}{l}\text { Directly influenceable and consistently } \\
\text { controllable by the management }\end{array}$ \\
\hline $\begin{array}{l}\text { Orientation } \\
\text { (arrangement of stores) }\end{array}$ & $\begin{array}{l}\text { Arrangement of stores evolved over time } \\
\text { Can only be indirectly facilitated by setting } \\
\text { up e.g. directories }\end{array}$ & $\begin{array}{l}\text { Arrangement of stores is considered in } \\
\text { planning stages } \\
\text { Can be adapted and is usually facilitated by } \\
\text { guidance systems, directories or information } \\
\text { desks }\end{array}$ \\
\hline $\begin{array}{l}\text { Infrastructural facilities } \\
\text { (cash supply, }\end{array}$ & $\begin{array}{l}\text { Not planned and limited influence on setting } \\
\text { them up }\end{array}$ & $\begin{array}{l}\text { Considered in a planning stage according } \\
\text { the needs of consumers }\end{array}$ \\
\hline $\begin{array}{l}\text { recreational areas, public } \\
\text { toilets) }\end{array}$ & $\begin{array}{l}\text { Dependent on local authorities, landlords, } \\
\text { tenants and banks }\end{array}$ & $\begin{array}{l}\text { Directly influenceable and controllable by } \\
\text { the management }\end{array}$ \\
\hline
\end{tabular}

\section{Conceptual model}

In order to identify those attributes that need to be targeted by the agglomeration management of different kinds of formats a conceptual model that proposes hypotheses in terms of effects between generic attributes of an agglomeration and attractiveness has been produced. This model is embedded in a simple Stimulus-Organism-Response model introduced by Finn and Louviere (1996): therein the stimuli account for the characteristics of an agglomeration in terms of the variables that can be directly or indirectly influenced by the agglomeration management or any other interest groups such as the tenants or local authorities. These characteristics are perceived as attributes by consumers and are then evaluated. The outcome of this evaluation process, and the integration of information and experiences with respect to an agglomeration, is that consumers will make an overall evaluation of the (overall) attractiveness of a format. This results in behavioral intensions and actual shopping behavior that can be measured in terms of the share of visits, share of spending and share of time spent in an agglomeration compared to others. 
The conceptual model comprises 26 hypotheses or positive effects between attributes, i.e. exogenous factors, of an agglomeration and the three dimensions of attractiveness, i.e. endogenous constructs (satisfaction $\left(\eta_{1}\right)$, retention proneness $\left(\eta_{2}\right)$, patronage intention $\left(\eta_{3}\right)$; see Figure 1$)$. As presented above, the generic attributes account for merchandise value $\left(\xi_{1}\right.$; e.g. Reynolds et al., 2002), product range ( $\xi_{2}$; e.g. Baker et al., 2002), personnel ( $\xi_{3}$; e.g. Raajpoot et al., 2008), accessibility ( $\xi_{4}$; e.g. Reimers and Clulow, 2004), parking ( $\xi_{5}$; e.g. Van der Waerden et al., 1998), retail tenant $\operatorname{mix}\left(\xi_{6}\right.$; e.g. Chebat et al., 2006), non retail tenant mix $\left(\xi_{7}\right.$; e.g. Wakefield and Baker, 1998), atmosphere ( $\xi_{8}$; e.g. Michon et al., 2005) orientation ( $\xi_{9}$; e.g. Chebat et al., 2005), and infrastructural facilities ( $\xi_{10}$; e.g. Baker et al., 2002).

Figure 1: Conceptual model

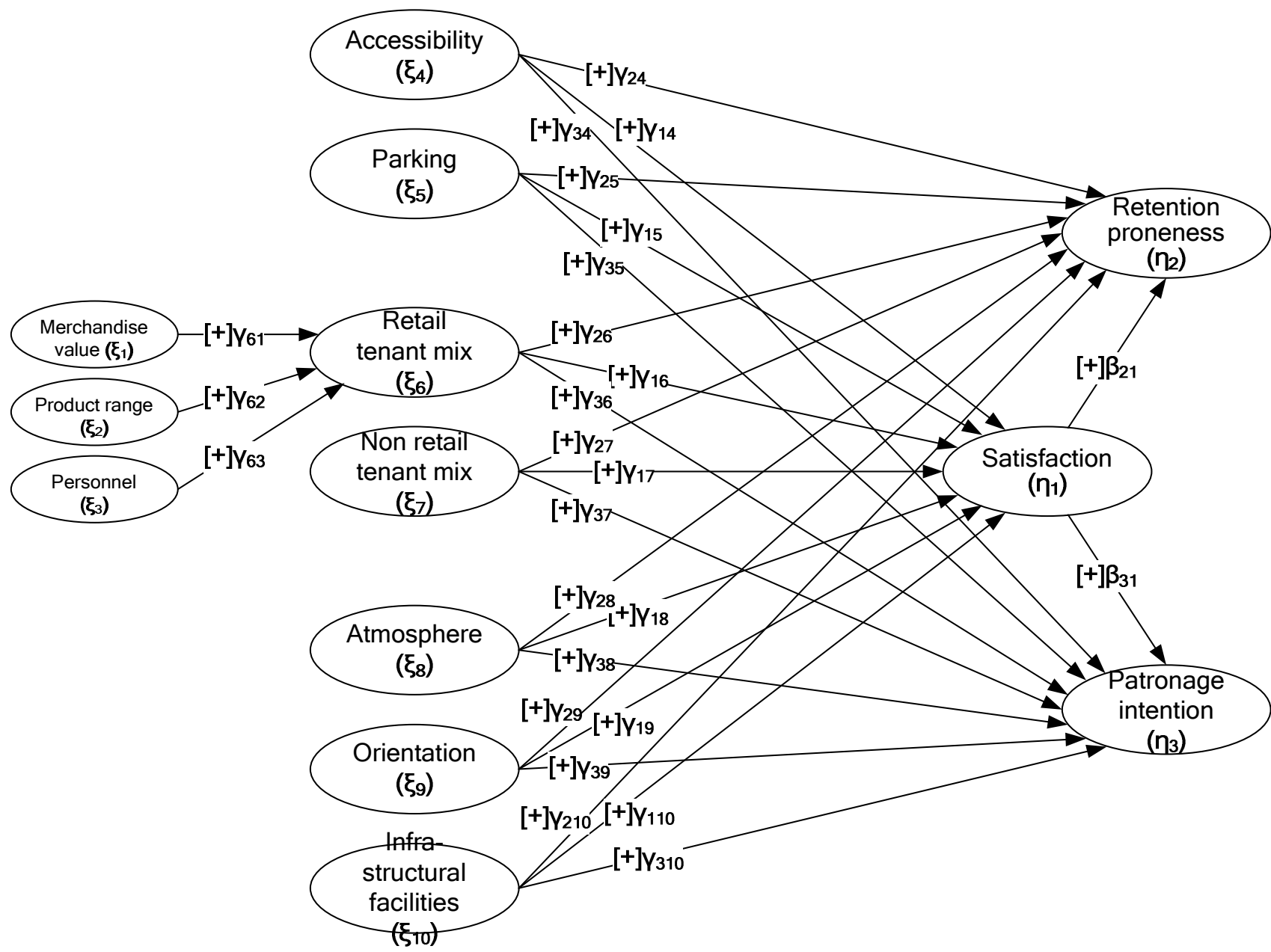

\section{Caption/notions:}

$\xi_{n} \ldots$ exogenous factors (ellipses); $\eta_{n} \ldots$ endogenous factors (ellipses); $\gamma_{n}$ and $\beta_{n} \ldots$ proposed positive $[+]$ effects ((also indicated by the arrows and arrows heads); inter-correlations between factors $(\Phi)$, indicators $\left(x_{n}, y_{n}\right)$ and error terms $\left(\varepsilon_{n}, \delta_{n}\right)$ are not shown; 
The first three factors operationalizing the retail offer of an agglomeration are proposed to have a direct effect on the retail tenant mix and thus only an indirect effect on attractiveness. All the other seven factors $\left(\xi_{4}-\xi_{10}\right)$ are proposed to have a direct effect. All attributes and dimensions of attractiveness are latent and reflective constructs and are operationalized by two or more indicators taken from literature presented above (see also the Appendix).

\section{Empirical study}

To test our model, an empirical study based in the capital city of a political district, as a subdivision of a province, with more than 25,000 inhabitants within a catchment population of 55,000 was conducted. Three agglomeration formats were identified: a town center, a strip center and a regional mall. Although the town center is the largest and most prominent agglomeration, it has lost some of its importance to the strip center on its edge together with the regional mall on the periphery of the town. Not only does the town center lack large scale retailers, but it has also suffered from the loss of attractive tenants compared to the other two formats. Across all formats, there is a degree of complementarity in their respective tenant mixes. Nevertheless, the town center competes with the strip center for fashion and sports products, and with the regional mall for fashion, electronics and IT products. In turn, the strip center and the mall compete with respect to groceries and fashion. Although the town center retailers try to work together through joint communication activities, no professional town center marketing exists. Apart from two small fashion-dominated department stores, the most common store formats are independently owned small/medium-sized specialty stores. In contrast, the strip center's management has attracted national and international retail chains including a grocery hypermarket. The regional mall is owned and managed by one of the largest national grocery retailers with the mix consisting of a hypermarket surrounded by smaller retail outlets. In both the strip center and the mall, a professional center management exists.

Across the retail portfolios of the three agglomerations, category killers such as IKEA for furniture, Mediamarkt/Saturn for electronics and Hennes \& Mauritz, Zara or Mango are not 
represented. These retailers can be found in the two provinces' capital cities, which both have a population of more than 100,000 and are within an hour's drive. As the different agglomeration formats within the provincial capitals include these larger scale retail outlets, they can be considered as being the supra-regional competitors for the three formats within the study location and as such form the focus of this paper.

Based on the work of Teller and Reutterer (2008), an in-vivo survey approach was applied. Thereby consumers were interviewed immediately after they had entered one of the three agglomeration formats focusing on their perceptions and shopping behaviors. Reference was made to Sudman (1980) when selecting the sample points - four entrance areas in the town center and two each in the strip center and the mall. At these points professional interviewers were able to intercept consumers. Every fifteen minutes consumers passing by a defined sampling mark were invited for interview. Since the number of consumers fluctuated throughout the day, there were variations in the number of selected respondents. During a period of three weeks a random sample of 486 in the town center, 228 in the strip center and 294 in the mall was collected with this representing the clientele of the three agglomeration formats. Applying a standardized questionnaire, which was administered by the interviewer, enabled the respondents to reflect upon and then record their shopping behavior and perceptions, together with their evaluations, with respect to the three agglomerations.

\section{Characterization of surveyed clientele}

Across the three clientele groups, significant differences were noted in terms of their demographic and behavioral characteristics (see Table 1). Whilst this is not reflective of the demographic structure of the population in the retail area at an individual level, it is at a household level. A major driver for this is the role split within households when it comes to shopping of different kinds, e.g. groceries, electronics, fashion. Overall, the town center clientele was characterized by being (comparably) young, female, having a lower individual income and level of educational attainment. Nevertheless, they visited the town center more often, spent more time and 
money, as measured by spend on food/beverages and entertainment, and went into more shops than consumers of the other agglomeration formats. Whilst the clientele of the strip center exhibited similar characteristics, they were older. In addition to behavioral differences, it was notable that the expenditure on food/beverages and entertainment was very low with this being a function of the lack of provision. In comparison, the mall clientele was more male dominated, considerably older and had an income that was significantly higher than consumers of the other two agglomeration formats. Apart from expenditure on food/beverages, the behavioral variables had the lowest figures as against the comparable figures for the other agglomerations. From a retailing perspective, the shopping behavior of the town center clientele was the most favorable with respect to frequency, spending and retention time.

By asking respondents to indicate which shopping destination was preferred, apart from the agglomeration in which the interview was conducted, the largest proportion of respondents in the town center $(77.5 \%)$ and the strip center $(57.7 \%)$ noted a preference for retail agglomerations in the two nearby provincial capital cities. This preference was much lower amongst respondents in the regional mall $(8.5 \%)$ with their preferred alternative being the strip center $(16.3 \%)$ and the town center $(11.2 \%)$. This suggests that the inter-regional competition between agglomerations, such as amongst the three agglomeration formats within the empirical study area, is quite low. In contrast, the supra-regional competition is notably higher, particularly for the town center. 
Table 2: Sample characterization

\begin{tabular}{|c|c|c|c|c|}
\hline \multirow[b]{2}{*}{ Demographic characteristics } & \multicolumn{3}{|c|}{ Agglomeration format } & \multirow[b]{2}{*}{$\Delta$} \\
\hline & Town center & Strip center & Regional mall & \\
\hline Gender $[\%]$ & $q=59.3$ & $q=63.6$ & $q=44.9$ & {$[\mathrm{~b}] /[\mathrm{c}]^{\dagger}$} \\
\hline Age (years) $[\mu(\sigma)]$ & $29.1(14.7)$ & $30.57(13.81)$ & $40.63(17.78)$ & {$[\mathrm{a}] /[\mathrm{b}] /[\mathrm{c}]^{\dagger \dagger}$} \\
\hline Individual Income (EUR) $[\mu(\sigma)]$ & $975.8(963.5)$ & $1,060.1(1003.3)$ & $1,203.9(839.7)$ & {$[\mathrm{b}] /[\mathrm{c}]^{\dagger \dagger}$} \\
\hline Household income (EUR) $[\mu(\sigma)]$ & $3,136.9(1841)$ & $3,034.3(1800.7)$ & $2,709.3(1895.1)$ & {$[\mathrm{b}] /[\mathrm{c}]^{\dagger \dagger}$} \\
\hline Number of persons in household $[\mu(\sigma)]$ & $3.6(1.8)$ & $3.4(1.5)$ & $3.2(1.7)$ & {$[\mathrm{b}] /[\mathrm{c}]^{\dagger \dagger}$} \\
\hline Education (Top 3) [\%] & $\begin{array}{l}\text { SecSchool }=61.1 \\
\text { A-level }=19.3 \\
\text { VocSchool }=8.6\end{array}$ & $\begin{array}{l}\text { SecSchool }=48.5 \\
\text { A-level }=31.7 \\
\text { VocSchool }=9.3\end{array}$ & $\begin{array}{l}\text { SecSchool }=47.6 \\
\text { A-level }=24.5 \\
\text { VocSchool }=9.5\end{array}$ & {$[\mathrm{~b}] /[\mathrm{c}]^{\dagger}$} \\
\hline \multicolumn{5}{|l|}{ Shopping behavior on sites } \\
\hline $\begin{array}{l}\text { Shopping (visiting) frequency per month } \\
{[\mu(\sigma)]}\end{array}$ & $9.3(8)$ & $4.6(4.9)$ & $4.5(5.8)$ & {$[\mathrm{a}] /[\mathrm{b}] /[\mathrm{c}]^{\dagger \dagger}$} \\
\hline $\begin{array}{l}\text { Expenditures on products/services (EUR) } \\
\text { per visit }[\mu(\sigma)]\end{array}$ & $48.8(56.6)$ & $46.2(45.9)$ & $34.2(34.3)$ & {$[\mathrm{b}] /[\mathrm{c}]^{\dagger \dagger}$} \\
\hline $\begin{array}{l}\text { Expenditures on food/entertainment (EUR) } \\
\text { per visit }[\mu(\sigma)]\end{array}$ & $16.3(26)$ & $3.4(6.5)$ & $6.5(8,2)$ & {$[\mathrm{a}] /[\mathrm{b}] /[\mathrm{c}]^{\dagger \dagger}$} \\
\hline Retention time $(\min )$ per visit $[\mu(\sigma)]$ & $109.1(60.7)$ & $53(35.4)$ & $39.9(25.2)$ & {$[\mathrm{a}] /[\mathrm{b}] /[\mathrm{c}]^{\dagger \dagger}$} \\
\hline Shops visited per trip on average $[\mu(\sigma)]$ & $3.4(1.8)$ & $2.8(1.7)$ & $2.2(1.4)$ & {$[\mathrm{a}] /[\mathrm{b}] /[\mathrm{c}]^{\dagger \dagger}$} \\
\hline Outshopping tendency (\% of respondents) & 71 & 69.3 & 60.2 & {$[\mathrm{~b}] /[\mathrm{c}]^{\dagger}$} \\
\hline \multicolumn{5}{|c|}{ 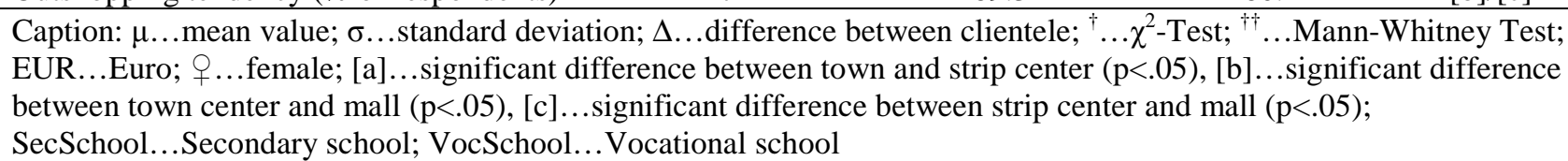 } \\
\hline
\end{tabular}

\section{Results}

In order to measure the effects between the latent (reflective) constructs, i.e. factors proposed in the model, a covariance-based structural equation modeling approach was applied e.g., Kline (2005) and Byrne (2001). The measurement validity of the exogenous and endogenous measurement models was tested according to Churchill (1979) and Bagozzi et al. (1991) (see Appendix). Cronbach Alpha coefficients were calculated for each factor and confirmatory analyses (CFA) for each measurement model. By interpreting the local fit measures, the internal consistency (Cronbach Alpha) can be considered to be satisfactory for all factors (>.7). The composite reliability of all factors (including the second order factor attractiveness) also meets the requirement to be above 0.6 (Fornell and Larcker, 1981) with the average variances extracted (AVE) in an acceptable range around 0.5 (Bagozzi and Yi, 1988). With regard to the constructs' discriminant validity, it can be said that the AVE is larger than the highest squared intercorrelation with every other factor in the measurement model (FLR<1; Fornell and Larcker, 1981). Based on these results, 
the local fit of the measurement models was satisfactory. The global fit was tested for the baseline model including all three samples. The calculated measures testing the absolute, incremental and parsimonious fit of our model meet the recommended values ( $\mathrm{Hu}$ and Bentler, 1991, 1999; Anderson and Gerbing, 1988; see caption of Table 3). From this, the empirical data of all the samples fits the proposed baseline model to a satisfactory degree.

As shown in Table 3, the size of the effect can be seen from the (standardized path) coefficients $(\gamma)$. By comparing these coefficients, a higher coefficient denoted that an exogenous factor had a relatively strong impact on an endogenous factor. Overall, ten effects were significant in the town center with eight each being significant for both the strip center and the regional mall. Consequently, the respective numbers of hypotheses were confirmed for each. Despite the heterogeneity of the three formats, the results were quite similar with regard to the main antecedents of the three endogenous factors $\left(\eta_{1}-\eta_{3}\right)$ operationalizing attractiveness.

In interpreting these results, all path coefficients $\left(\beta_{21}\right.$ and $\left.\beta_{31}\right)$, which indicate the impact of effects between the three endogenous factors, were significant. This means that any exogenous factor directly affecting 'satisfaction' $\left(\eta_{1}\right)$ also had an indirect affect on 'retention proneness' $\left(\eta_{2}\right)$ and 'patronage intention' $\left(\eta_{3}\right)$, and is, therefore, an antecedent for all three endogenous factors. For all three agglomerations, the 'retail tenant mix' $\left(\xi_{6}\right)$ and 'atmosphere' $\left(\xi_{8}\right)$ were the most important influencing factors. More specifically the effects of $\xi_{6}$, as a tenant related factor were strongest in the town center in that there was a direct influence on the three endogenous factors. For the other agglomerations, a direct effect for this factor was only observable for 'satisfaction'. At a disaggregated level, the 'retail tenant mix' in all the agglomerations was strongly affected by the 'product range' $\left(\xi_{2}\right)$ offered. However, 'personnel' $\left(\xi_{3}\right)$ and 'merchandise value' $\left(\xi_{1}\right)$ only impacted upon the 'retail tenant $\operatorname{mix}(\mathrm{es})$ ' for the strip center and regional mall, respectively. These two significant factors only had an indirect influence on the endogenous factors. 
Table 3: Antecedents of agglomerations' attractiveness

\begin{tabular}{|c|c|c|c|c|}
\hline \multirow[b]{2}{*}{$\begin{array}{l}\text { Hypo- } \\
\text { theses }\end{array}$} & \multirow[b]{2}{*}{$\begin{array}{l}\text { Effects between exogenous }(\xi) \text { and endogenous } \\
\text { factors }(\eta)\end{array}$} & \multicolumn{3}{|c|}{ Agglomeration format } \\
\hline & & $\begin{array}{c}\text { Town center } \\
(\mathrm{n}=486)\end{array}$ & $\begin{array}{l}\text { Strip center } \\
(\mathrm{n}=228)\end{array}$ & $\begin{array}{c}\text { Regional mall } \\
(\mathrm{n}=294)\end{array}$ \\
\hline $\mathrm{H}_{14} / \gamma_{14}$ & Accessibility $\left(\xi_{4}\right) \rightarrow$ Satisfaction $\left(\eta_{1}\right)$ & - & - & - \\
\hline $\mathrm{H}_{24} / \gamma_{24}$ & Accessibility $\left(\xi_{4}\right) \rightarrow$ Retention proneness $\left(\eta_{2}\right)$ & - & - & - \\
\hline $\mathrm{H}_{34} / \gamma_{34}$ & Accessibility $\left(\xi_{4}\right) \rightarrow$ Patronage intention $\left(\eta_{3}\right)$ & - & - & - \\
\hline $\mathrm{H}_{15} / \gamma_{15}$ & Parking $\left(\xi_{5}\right) \rightarrow$ Satisfaction $\left(\eta_{1}\right)$ & - & - & - \\
\hline $\mathrm{H}_{25} / \gamma_{25}$ & Parking $\left(\xi_{5}\right) \rightarrow$ Retention proneness $\left(\eta_{2}\right)$ & - & - & - \\
\hline $\mathrm{H}_{35} / \gamma_{35}$ & Parking $\left(\xi_{5}\right) \rightarrow$ Patronage intention $\left(\eta_{3}\right)$ & - & - & - \\
\hline $\mathrm{H}_{16} / \gamma_{16}$ & Retail tenant mix $\left(\xi_{6}\right) \rightarrow$ Satisfaction $\left(\eta_{1}\right)$ & $.489 * * *$ & $.399 * * *$ & $.615^{* * *}$ \\
\hline $\mathrm{H}_{26} / \gamma_{26}$ & Retail tenant mix $\left(\xi_{6}\right) \rightarrow$ Retention proneness $\left(\eta_{2}\right)$ & $.147 *$ & - & - \\
\hline $\mathrm{H}_{36} / \gamma_{36}$ & Retail tenant mix $\left(\xi_{6}\right) \rightarrow$ Patronage intention $\left(\eta_{3}\right)$ & $.184^{*}$ & - & - \\
\hline $\mathrm{H}_{17} / \gamma_{17}$ & Non retail tenant mix $\left(\xi_{7}\right) \rightarrow$ Satisfaction $\left(\eta_{1}\right)$ & - & - & - \\
\hline $\mathrm{H}_{27} / \gamma_{27}$ & Non retail tenant mix $\left(\xi_{7}\right) \rightarrow$ Retention proneness & - & - & $.186^{*}$ \\
\hline $\mathrm{H}_{37} / \gamma_{37}$ & Non retail tenant mix $\left(\xi_{7}\right) \rightarrow$ Patronage intention & - & - & - \\
\hline $\mathrm{H}_{18} / \gamma_{18}$ & Atmosphere $\left(\xi_{8}\right) \rightarrow$ Satisfaction $\left(\eta_{1}\right)$ & $.244 * * *$ & $.385^{* * *}$ & $.174 *$ \\
\hline $\mathrm{H}_{28} / \gamma_{28}$ & Atmosphere $\left(\xi_{8}\right) \rightarrow$ Retention proneness $\left(\eta_{2}\right)$ & $.386^{* * *}$ & $.368 * *$ & $.311 * *$ \\
\hline $\mathrm{H}_{38} / \gamma_{38}$ & Atmosphere $\left(\xi_{8}\right) \rightarrow$ Patronage intention $\left(\eta_{3}\right)$ & - & - & - \\
\hline $\mathrm{H}_{19} / \gamma_{19}$ & Orientation $\left(\xi_{9}\right) \rightarrow$ Satisfaction $\left(\eta_{1}\right)$ & - & - & - \\
\hline $\mathrm{H}_{29} / \gamma_{29}$ & Orientation $\left(\xi_{9}\right) \rightarrow$ Retention proneness $\left(\eta_{2}\right)$ & - & - & - \\
\hline $\mathrm{H}_{39} / \gamma_{39}$ & Orientation $\left(\xi_{9}\right) \rightarrow$ Patronage intention $\left(\eta_{3}\right)$ & $.209^{*}$ & $.388 * *$ & - \\
\hline $\mathrm{H}_{110} / \gamma_{110}$ & Infrastructural facilities $\left(\xi_{10}\right) \rightarrow$ Satisfaction $\left(\eta_{1}\right)$ & $.213 * *$ & - & - \\
\hline $\mathrm{H}_{210} / \gamma_{210}$ & Infrastructural facilities $\left(\xi_{10}\right) \rightarrow$ Retention & - & - & - \\
\hline $\mathrm{H}_{310} / \gamma_{310}$ & Infrastructural facilities $\left(\xi_{10}\right) \rightarrow$ Patronage intention & - & - & - \\
\hline $\mathrm{H}_{61} / \gamma_{61}$ & Merchandise value $\left(\xi_{1}\right) \rightarrow$ Retail tenant mix $\left(\xi_{6}\right)$ & - & - & $.226^{*}$ \\
\hline $\mathrm{H}_{62} / \gamma_{62}$ & Product range $\left(\xi_{2}\right) \rightarrow$ Retail tenant mix $\left(\xi_{6}\right)$ & $.672 * * *$ & $.522 * * *$ & $.635 * * *$ \\
\hline $\mathrm{H}_{63} / \gamma_{63}$ & Personnel $\left(\xi_{3}\right) \rightarrow$ Retail tenant mix $\left(\xi_{6}\right)$ & - & $.206^{* *}$ & - \\
\hline$\beta_{21}$ & Satisfaction $\left(\eta_{1}\right) \rightarrow$ Retention proneness $\left(\eta_{2}\right)$ & $.130^{*}$ & $.274 * *$ & $.307^{*}$ \\
\hline$\beta_{31}$ & Satisfaction $\left(\eta_{1}\right) \rightarrow$ Patronage intention $\left(\eta_{3}\right)$ & $.236 * *$ & $.629 * * *$ & $.628 * * *$ \\
\hline
\end{tabular}

Caption: $\gamma \ldots$..standardized regression weights; -...t-values are not significant and consequently $\gamma$ is not shown; *...t-values are significant $(\mathrm{p}<.05) ; * * \ldots \mathrm{t}$-values are significant $(\mathrm{p}<.01) ; * * * \ldots \mathrm{t}$-values are significant $(\mathrm{p}<.001)$

Notions: Global fit measures regarding the baseline model (recommended cut-off values in brackets): Absolute fit measure: RMSEA $(<.08)=.033$; Incremental fit measures: TLI/CFI (>.9/>.9)=.902/.916; Parsimony fit measures: Normed $\chi^{2}(\mathrm{CMIN} / \mathrm{df})(<3)=2.064$; Degrees of freedom=1,809; Squared multiple correlations $\left(\mathrm{r}^{2}\right)$ : Town center: $\xi_{6}=.633 ; \eta_{1}=.517 ; \eta_{2}=.301 ; \eta_{3}=.254 ;$ Strip center: $\xi_{6}=.573 ; \eta_{1}=.432 ; \eta_{2}=.339 ; \eta_{3}=.440 ;$ regional mall: $\xi_{6}=.614$; $\eta_{1}=.639 ; \eta_{2}=.429 ; \eta_{3}=.557$

'Atmosphere' $\left(\xi_{8}\right)$ had a direct effect on 'satisfaction' and 'retention proneness' for all three settings with 'patronage intention' only being indirectly affected. Thereafter, the observable effects were mostly of middling or low significance. The 'non retail tenant mix' $\left(\xi_{7}\right)$ had a significant influence on 'retention proneness' in the regional mall and, similarly, 'orientation' ( $\left.\xi_{9}\right)$ played an important role with regard to 'patronage intention' for the town center and strip center. The infrastructural elements had a significant impact on 'satisfaction' but only for the town center. 
Across all the agglomerations, 'accessibility' $\left(\xi_{4}\right)$ and 'parking' (conditions) $\left(\xi_{5}\right)$ did not impact on any of the endogenous factors and can therefore be seen as non determinant.

\section{Discussion}

The model was tested in three agglomerations that are different with respect to their structural characteristics including size, location or building structure and with respect to the way they are managed. By comparing both the demographic and the behavioral characteristics of our representative sample, we face significant differences and thus confirm a "clientele effect" (Kahn and McAlister, 1997) at an agglomeration level. This means that despite all the three agglomerations appealing to the same market, segmentation takes place driven by the diverse supply of each store cluster or - in other words - the attributes and the attractiveness of each agglomeration. The diversity of attributes is evident based on the significantly different ratings of each variable (Kruskal-Wallis test, $\mathrm{p}<.05$ ) except those operationalizing accessibility. A historic view of development of the three agglomerations shows an increasingly complementarity of the retail and non retail offers. The rising pressure from the supra-regional agglomerations on the doorsteps of the political districts confirms Teller's (2008) notions of the problematic situation faced by smaller regional retail agglomerations of all formats.

Taking into account the heterogeneity of our agglomerations and their clientele we face a remarkable homogeneity of results in terms of those attributes that affect attractiveness - in terms of our three endogenous factors - most significantly. The retail tenant mix and the product range affecting the tenant mix determining the attractiveness most considerably in all three settings. This reveals the extraordinary importance of the retail, or more specifically the product offer, and the store selection available to consumers in the agglomerations. This major finding confirms the notions of e.g. Teller and Reutterer (2008), Anselmsson (2006), Leo and Philippe (2002), Van Kenhove et al. (1999) or Alzubaidi et al. (1997) for smaller and regional agglomeration formats. The atmosphere can be seen as the other major antecedent in all three agglomeration settings. 
Consequently, the findings from Teller and Reutterer (2008), Michon et al. (2005), Baker et al. (2002), Ruiz et al. (2004), Bellenger et al. (1977) can also be confirmed.

The notions of Raajpoot et al. (2008) regarding the importance of the sales personnel (which is mediated by the retail tenant mix) can only be confirmed for the strip center. The same is true for the merchandise value but only for the regional mall in accordance with the findings from Reynolds et al. (2002). The infrastructural facilities are only determinants of attractiveness in the town center and thus only confirming the finding from Baker et al. (2002) for this evolved format. The orientation solely affects the patronage intention in the town and strip center confirming the results of Chebat et al. (2005). Furthermore, the non retail tenant mix only influences the retention proneness in the regional mall as supported by Wakefield and Baker (1998).

Alongside these characteristics, it was notable that the hypotheses indicated that others were of no importance. In particular, accessibility and parking were of no significance. This finding contrasts with van der Waerden et al., (1998), Oppewal and Holyoake (2004), and Reimers and Clulow (2004) who have focused on different kinds of retail agglomerations in particular created and supra-regional agglomeration formats.

\section{Conclusion}

The examination of our findings with reference to the extant literature results in a considerable number of disconfirmed hypotheses. This leads to the assumption that evolved agglomeration formats in general and regional ones in particular are different in many respects and thus require special consideration and increased attention in marketing and retail research.

Our findings clearly identify that the tenant mix, the product range and the atmosphere are the major antecedents of attractiveness. This consequently shows which stakeholder group is most capable of increasing the agglomerations' attractiveness of diverse formats and consequently their competitiveness. The effective management of retail tenants can change the attractiveness of their location and their environment, respectively. Shopping center and/or town center management can assist in this process by assembling or amending the optimum mix of retail tenants but also by 
supporting the existing tenants through improving the overall atmosphere depending on the format. Nevertheless, the empirical findings appear to contradict Reimers and Clulow's (2009) assertion that the major task of agglomeration management should be to increase the convenience of their agglomeration in terms of consumers' physical accessibility. To the contrary this paper confirms Teller and Reutterer's (2008) suggestion that making the retail-related offerings of an agglomeration more attractive to consumers can compensate for convenience related shortcomings - i.e. accessibility, parking or infrastructural facilities - of agglomerations, in particular evolved formats.

It is also worth mentioning that the homogeneity of major antecedents of attractiveness of the three investigated formats provides an indirect explanation why particular evolved agglomerations struggle against their created counterparts. Since the power of the management of evolved formats in relation to the tenants and other stakeholder groups is constrained the implementation of a consistent management and marketing strategy is limited and dependent on good-will and cooperation. Our findings emphasize the importance of agglomerations tenants working together - e.g. under the umbrella of a professional center or place management/marketing concept - to increase the attractiveness of the whole agglomeration and as a result their own competitiveness in the marketplace.

\section{Limitations and directions for further research}

The empirical evidence can only be applied to similar retail settings and agglomeration formats with the result being that where retail provision within a town center includes a powerful (inner city) shopping center or department store other results could be obtained. This accounts in particular for the marginal presence of the non retail tenants in all three settings. Apart from these spatial and structural characteristics, the specific shopping or visiting situations around which the surveys occurred limited the transferability of the research. An in-vitro survey approach, which involves home interviews, may lead to different results (Teller and Reutterer, 2008). By applying the ideas of Van Kenhove et al. (1999) and using the in-vivo approach, the shopping situation can 
have an impact on the perception of attributes and the evaluation of attractiveness. This paper did not differentiate between demographic or psychographic sub-samples within each agglomeration format. According to the notions of El-Adly (2007) the moderating effects of segmentation criteria can therefore form the basis of further research.

Based on our findings and the discussion we see several important issues to be considered in further research endeavors. (1) According to the research questions our conceptual model considers the relationship between the exogenous factors only to a minimum degree. For example the orientation, infrastructural facilities and the retail offer can also be seen as influencing factors towards the overall atmosphere. As a result further research should pay more attention to these interdependencies between these factors in order to give agglomeration managers deeper insights into how to use dependent marketing mix instruments. (2) Furthermore a future research agenda should consider the relationship between agglomerations and thereby include both created and evolved formats. In our setting it would be interesting to examine to what extent the three agglomerations can cooperate in order to compete with the supra-regional agglomeration formats. In particular on a regional level such a 'co-opetition' between agglomerations could be considered as a strategy to survive against their supra-regional counterparts. (3) Finally the inclusion of possible moderators, such as demographic and psychographic factors, along with situational variables, could serve to further enrich our understanding of consumer patronage behavior towards different retail agglomeration formats.

\section{References}

Alzubaidi, H. and Vignali, C. (1997), “Town center versus out-of-town shopping: A consumer perspective”, International Journal of Retail \& Distribution Management, Vol. 25 No. 2/3, pp. 78-89.

Anderson, J.C. and Gerbing, D.W. (1988), "Structural equation modelling in practice: A review and recommended two-step approach”, Psychological Bulletin, Vol. 103 No. 3, pp. 411-423. 
Anselmsson, J. (2006), "Sources of customer satisfaction with shopping malls: A comparative study of different customer segments", International Review of Retail, Distribution \& Consumer Research, Vol. 16 No. 1, pp. 115-138.

Arentze, T. A. and Timmermans, H. J. P. (2001), "Deriving performance indicators from models of multipurpose shopping behaviour." Journal of Retailing and Consumer Services, Vol. 8 No. 6, pp. $325-34$.

Bacon, R. W. (1995), “Combined trips and the frequency of shopping”, Journal of Retailing and Consumer Services, Vol. 2 No. 3, pp. 175-183.

Bagozzi, R. P. and Yi, Y. (1988), "On the evaluation of structural equation models”, Journal of the Academy of Marketing Science, Vol. 16 No. 1, pp. 74-94.

Bagozzi, R.P., Yi, Y. and Phillips, L.W. (1991), “Assessing construct validity in organizational research", Administrative Science Quarterly, Vol. 36 No. 3, pp. 421-458.

Baker, J., Parasuraman, A., Grewal, D. and Voss, G. B. (2002), “The influence of multiple store environment cues on perceived merchandise value and patronage intentions", Journal of Marketing, Vol. 66 No. 2, pp. 120-141.

Bearden, W. O. (1977), "Determinant attributes of store patronage - Downtown versus outlying shopping centers", Journal of Retailing, Vol. 53 No. 2, pp. 15-22.

Bellenger, D. N. (1977), "Shopping center patronage motives”, Journal of Retailing, Vol. 53 No. 2, pp. 29-38.

Berman B. and Evans J. R. (2009), Retail management. A strategic approach, Pearson Education, Upper Saddle River/NJ.

Byrne, B. M. (2001), Structural equation modelling with AMOS: Basic concepts, applications, and programming, Lawrence Erlbaum Associates, New Jersey, Mahwah, London.

Chebat Jean C., Gélinas-Chebat, C., Therrien, K. (2005), "Lost in a mall, the effects of gender, familiarity with the shopping mall and the shopping values on shoppers' wayfinding processes”, Journal of Business Research, Vol. 58 No. 11, pp. 1590-1598. 
Chebat J. C., Sirgy, M. J. and St-James, V. (2006), "Upscale image transfer from malls to stores: A self-image congruence explanation”, Journal of Business Research, Vol. 59 No. 12, pp. 12881296.

Churchill, G. A. (1979), “A paradigm for developing better measures of marketing constructs”, Journal of Marketing Research, Vol. 16 No. 1, pp. 64-73.

Dellaert, B. G. C., Arentze, T. A., Bierlaire, M., Borgers, A. W. J. and Timmermans, H. J. P. (1998), "Investigating consumers' tendency to combine multiple shopping purposes and destinations", Journal of Marketing Research, Vol. 35 No. 2, pp. 177-188.

Dennis, C., Marsland, D. and Newman A. (2005), Objects of desire: consumer behaviour in shopping center choices, Palgrave MacMillan, Hampshire, New York.

El-Adly, M. I. (2007), “Shopping malls attractiveness: a segmentation approach", International Journal of Retail \& Distribution Management, Vol. 35 No. 11, pp. 936-950.

Evanschitzky, H., Baumgaarth, C., Hubbard, R. and Armstrong, J.S. (2007), “Replication research's disturbing trend", Journal of Business Research, Vol. 60 No. 4, pp. 411-415.

Finn, A. and Louviere, J. J. (1996), "Shopping center image, consideration, and choice: anchor store contribution", Journal of Business Research, Vol. 35 No. 3, pp. 241-251.

Fornell, C. and Larcker, D. F. (1981), "Evaluating structural equation models with unobservable variables and measurement error", Journal of Marketing Research, Vol. 18 No. 1, pp. 39-40.

Guy, C. M. (2007), Planning for retail development. A critical view of British experience, Routledge, London.

Hoffman, D. K. and Turley, L. W. (2002), “Atmospherics, service encounters and consumer decision making: An integrative perspective”, Journal of Marketing Theory and Practice, Vol. 10 No. 3, pp. 33-48.

Howard, E. (1997), “The management of shopping centers: conflict or collaboration?", International Review of Retail, Distribution and Consumer Research, Vol. 7 No. 3, pp. 263285. 
Hu, L. and Bentler, P. M. (1991), "Fit indices in covariance structure modelling: sensitivity to underparameterized model misspecification”, Psychological Methods, Vol. 3 No. 4, pp. 425453.

Hu, L. and Bentler, P. M. (1999), "Cutoff criteria for fit indexes in covariance structure analysis: Conventional criteria versus new alternatives", Structural Equation Modelling, Vol. 6 No. 1, pp. 1-55.

Ingene, C. A. (1984), "Productivity and Functional Shifting in Spatial Retailing: Private and Social Perspectives", Journal of Retailing and Consumer Services, Vol. 60 No 3, pp. 15-26.

Kahn, B. E. and McAlister, L. M. (1997), Grocery revolution: The new focus on the consumer, Addison-Wesley, Reading.

Kline, R. B. (2005), Principles and practice of structural equation modeling, The Guilford Press, New York, London.

Leo, P. Y. and Philippe J. (2002), "Retail centers: Location and consumer's satisfaction”, Service Industries Journal, Vol. 22 No. 1, pp. 122-146.

Michon, R., Chebat, J. C. and Turley, L. W. (2005), "Mall atmospherics: the interaction effects of the mall environment on shopping behavior." Journal of Business Research, Vol. 58 No. 5, pp. 576-583.

Nelson, R. L. (1958), The selection of retail locations, F.W. Dodge Corporation, New York.

Oppewal, H. and Holyoake, B. (2004), "Bundling and retail agglomeration effects on shopping behavior", Journal of Retailing and Consumer Services, Vol. 11 No. 2, pp. 61-74.

Raajpoot, N. A., Sharma, A. and Chebat, J. C. (2008), "The role of gender and work status in shopping center patronage", Journal of Business Research, Vol. 61 No. 8), pp. 825-833.

Reimers V. and Clulow, V. (2009), "Retail centers: it s time to make them convenient", International Journal of Retail \& Distribution Management, Vol. 37 No. 7, pp. 541-562. 
Reimers, V. and Clulow, V. (2004), "Retail concentration: a comparison of spatial convenience in shopping strips and shopping centers", Journal of Retailing and Consumer Services, Vol. 11 No. 4, pp. 207-221.

Reynolds, K. E., Ganesh, J., Luckett, M. (2002), “Traditional malls vs. factory outlets: comparing shopper typologies and implications for retail strategy", Journal of Business Research, Vol. 55 No. 9, pp. 687-696.

Ruiz, J. P., Chebat, J. C. and Hansen, P. (2004), “Another trip to the mall: a segmentation study of customers based on their activities”, Journal of Retailing and Consumer Services, Vol. 11 No. 6, pp. 333-350.

Schnedlitz, P. and Teller, C. (2008), "Das Einkaufszentrum als Agglomerationsklasse - begriffliche Diskussion und empirische Evaluierung von Agglomerationseffekten“ [Shopping centers as a distinct agglomeration format - conceptual discussion and empirical evaluation of agglomeration effects], in Gruber, M. (Ed), Agglomerationseffekte und Bestandverhaeltnisse in Einkaufszentren [Agglomeration effects and leasing agreements in shopping centers], Manz, Vienna, pp. 1-52

Sudman, S. (1980), "Improving the quality of shopping center sampling", Journal of Marketing Research, Vol. 17 No. 4): 423-431.

Tang, C. S., Bell, D. R. and Ho, T.-H. (2001), "Store choice and shopping behavior: How price format works", California Management Review, Vol. 43 No. 2, pp. 56-74.

Teller, C. and Reutterer, T. (2008), “The evolving concept of retail attractiveness: What makes retail agglomerations attractive when customers shop at them?", Journal of Retailing and Consumer Services, Vol. 15 No. 3, pp. 127-143.

Teller, C., Reutterer, T. and Schnedlitz, P. (2008), "Hedonic and utilitarian shopper types and created retail agglomerations", International Review of Retail, Distribution and Consumer Research, Vol. 18 No. 3, pp. 283-309. 
Teller, C. (2008), "Shopping streets versus shopping malls - determinants of agglomeration format attractiveness from the consumers' point of view", International Review of Retail, Distribution and Consumer Research, Vol. 18 No. 4, pp. 381-403.

Van der Waerden, P., Borgers, A. and Timmermans, H. (1998), "The impact of the parking situation in shopping centers on store choice behaviour”, GeoJournal, Vol. 45 No. 4, pp. 309315.

Van Kenhove, P., de Wulf, K. and van Waterschoot, W. (1999), "The impact of task definition on store-attribute saliences and store choice", Journal of Retailing, Vol. 75 No. 1, pp. 125-137.

Wakefield, K. L. and Baker, J.. (1998), "Excitement at the mall: Determinants and effects on shopping response", Journal of Retailing, Vol. 74 No. 4, pp. 515-539.

Warnaby, G. and Medway, D. (2004), "The role of place marketing as a competitive response by town centers to out-of-town retail developments", International Review of Retail, Distribution and Consumer Research, Vol. 14 No. 4, pp. 457-477.

Warnaby, G., Bennison, D. and Davies, B.J. (2005), "Retailing and the marketing of urban places: a UK perspective", International Review of Retail, Distribution and Consumer Research, Vol. 15 No. 2, pp. 191-215.

Woodside, A. G. and Trappey, R. J. I. (1992), "Finding out why customers shop your store and buy your brand: Automatic cognitive processing models of primary choice”, Journal of Advertising Research, Vol. 32 No. 6, pp. 59-78.

Wrigley, N. and Lowe, M. (2002), Reading retail: a geographical perspective on retailing and consumption spaces, Arnold, London. 


\section{Appendix}

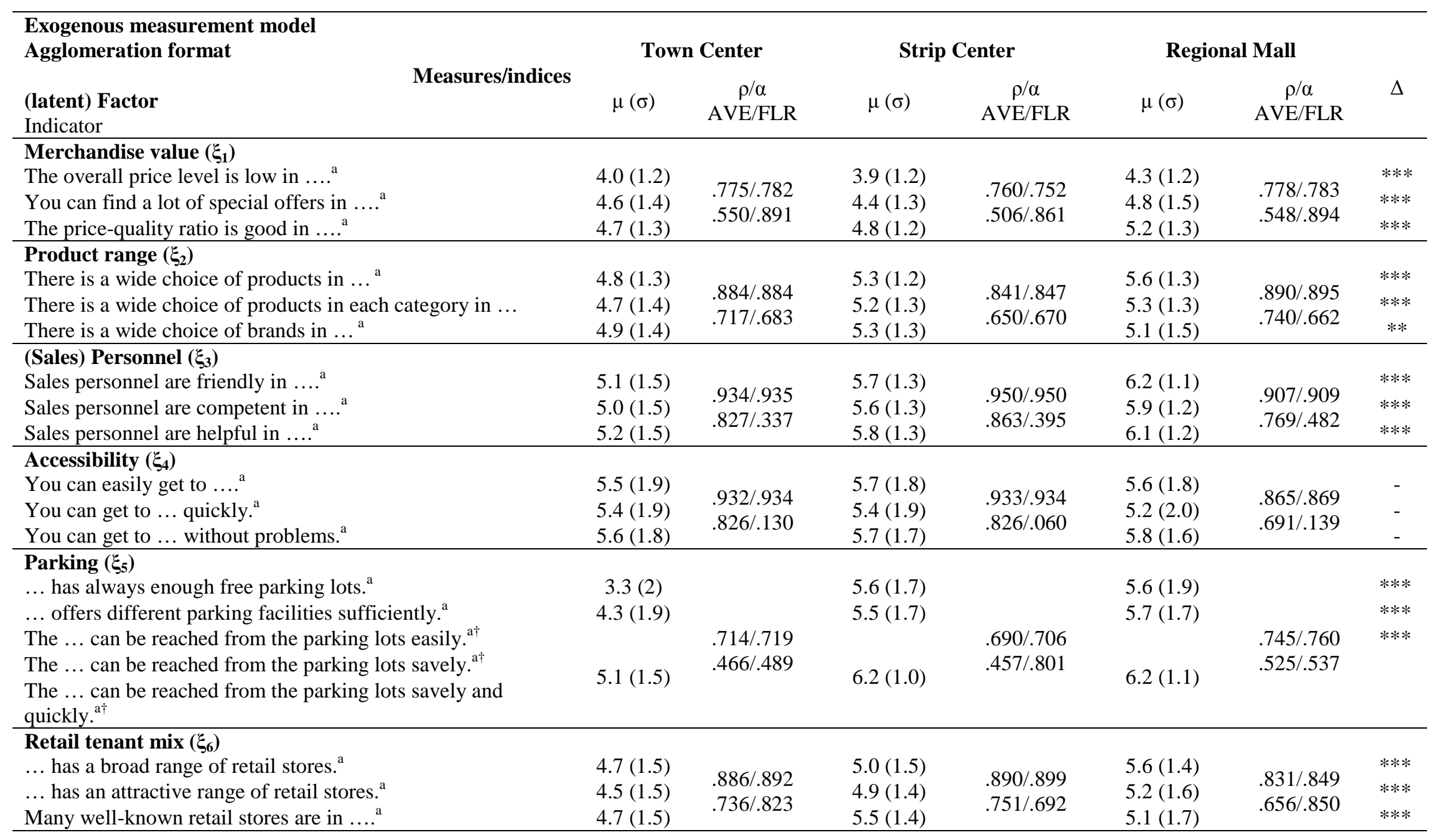




\begin{tabular}{|c|c|c|c|c|c|c|c|}
\hline $\begin{array}{l}\text { Exogenous measurement model (continued) } \\
\text { Agglomeration format }\end{array}$ & Tow & Center & Stri & nter & Regic & Mall & \\
\hline $\begin{array}{l}\text { (latent) Factor } \\
\text { Indicator }\end{array}$ & $\mu(\sigma)$ & $\begin{array}{c}\rho / \alpha \\
\text { AVE/FLR }\end{array}$ & $\mu(\sigma)$ & $\begin{array}{c}\rho / \alpha \\
\text { AVE/FLR }\end{array}$ & $\mu(\sigma)$ & $\begin{array}{c}\rho / \alpha \\
\text { AVE/FLR }\end{array}$ & $\Delta$ \\
\hline $\begin{array}{l}\text { Non retail tenant mix }\left(\xi_{7}\right) \\
\ldots \text { has a broad range of bars and restaurants. } \\
\ldots \text { offers a broad range of service stores. } \\
\text { a }\end{array}$ & $\begin{array}{l}5.0(1.6) \\
4.1(1.7)\end{array}$ & $\begin{array}{l}.645 / .649 \\
.481 / .783\end{array}$ & $\begin{array}{l}2.9(1.5) \\
2.2(1.5)\end{array}$ & $\begin{array}{l}.792 / .793 \\
.657 / .517\end{array}$ & $\begin{array}{l}3.3(2.0) \\
2.5(1.7)\end{array}$ & $\begin{array}{l}.740 / .747 \\
.598 / .415\end{array}$ & $\begin{array}{l}* * * \\
* * *\end{array}$ \\
\hline $\begin{array}{l}\text { Atmosphere }\left(\xi_{8}\right) \\
\text { The odour is not disturbing in .... }{ }^{\dagger} \\
\text { The air is pleasant in .... } \\
\text { The temperature is pleasant in .... }{ }^{\dagger}{ }^{\dagger} \\
\text { The light is pleasant in .... } \\
\text { It is always clean in .... }\end{array}$ & $5.2(1.2)$ & $\begin{array}{l}.850 / .892 \\
.750 / .506\end{array}$ & $5.8(1.0)$ & $\begin{array}{l}.887 / .926 \\
.817 / .498\end{array}$ & $6.0(1.0)$ & $\begin{array}{l}.895 / .930 \\
.825 / .547\end{array}$ & $* * *$ \\
\hline $\begin{array}{l}\text { The architecture is appealing in .... } \\
\text { There is a good mood in .... } \\
\text { The atmosphere is pleasant in .... }\end{array}$ & $\begin{array}{l}4.9(1.4) \\
5.0(1.4)\end{array}$ & 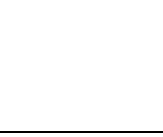 & $\begin{array}{l}5.2(1.3) \\
5.2(1.4)\end{array}$ & 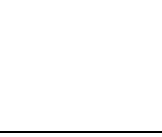 & $\begin{array}{l}5.5(1.4) \\
5.6(1.3)\end{array}$ & 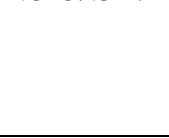 & $\begin{array}{ll}* * * \\
* * *\end{array}$ \\
\hline $\begin{array}{l}\text { Orientation }\left(\xi_{9}\right) \\
\text { You can move around without problems in .... }{ }^{\dagger}{ }^{\dagger} \\
\text { You can move around safely and quickly in .... } \\
\text { You can easily orientate yourself within .... } \\
\text { Stores are arranged clearly in .... }\end{array}$ & $\begin{array}{l}6.1(1.2) \\
5.3(1.5)\end{array}$ & $\begin{array}{l}.688 / .695 \\
.436 / .871\end{array}$ & $\begin{array}{l}6.3(1.0) \\
6.3(1.0)\end{array}$ & $\begin{array}{l}.784 / .785 \\
.557 / .731\end{array}$ & $\begin{array}{l}6.4(0.8) \\
6.3(1.0) \\
6.2(1.0)\end{array}$ & $\begin{array}{l}.822 / .847 \\
.658 / .686\end{array}$ & $\begin{array}{c}* \\
* * * \\
*\end{array}$ \\
\hline $\begin{array}{l}\text { Infrastructural facilities }\left(\boldsymbol{\xi}_{10}\right) \\
\text { There are enough washrooms in .... } \\
\text { There are enough cash dispensers in .... } \\
\text { There are enough recreational areas in .... }\end{array}$ & $\begin{array}{l}3.3(1.9) \\
5.0(1.6) \\
4.1(1.8)\end{array}$ & $\begin{array}{l}.719 / .721 \\
.465 / .724\end{array}$ & $\begin{array}{l}3.7(1.9) \\
2.1(1.8) \\
2.5(1.7)\end{array}$ & $\begin{array}{l}.682 / .691 \\
.432 / .786\end{array}$ & $\begin{array}{l}5.6(1.7) \\
5.9(1.6) \\
4.7(2.0)\end{array}$ & $\begin{array}{l}.696 / .700 \\
.438 / .877\end{array}$ & $\begin{array}{l}* * * \\
* * * \\
* * *\end{array}$ \\
\hline
\end{tabular}




\begin{tabular}{|c|c|c|c|c|c|c|c|}
\hline \multirow{2}{*}{$\begin{array}{l}\text { Endogenous measurement model } \\
\text { Agglomeration format } \\
\text { (latent) Factor } \\
\text { Indicator }\end{array}$} & \multicolumn{2}{|c|}{ Town Center } & \multicolumn{2}{|c|}{ Strip Center } & \multicolumn{2}{|c|}{ Regional Mall } & \multirow[t]{2}{*}{$\Delta$} \\
\hline & $\mu(\sigma)$ & $\begin{array}{c}\rho / \alpha \\
\text { AVE/FLR }\end{array}$ & $\mu(\sigma)$ & $\begin{array}{c}\rho / \alpha \\
\text { AVE/FLR }\end{array}$ & $\mu(\sigma)$ & $\begin{array}{c}\rho / \alpha \\
\text { AVE/FLR }\end{array}$ & \\
\hline \multicolumn{8}{|l|}{ Satisfaction $\left(\eta_{1}\right)$} \\
\hline How satisfied are you with ... (very dis-/-satisfied) ${ }^{\mathrm{b}}$ & $5.1(1.4)$ & \multirow{3}{*}{$\begin{array}{l}.844 / .848 \\
.652 / .255\end{array}$} & $5.8(1.1)$ & \multirow{3}{*}{$\begin{array}{l}.750 / .764 \\
.523 / .539\end{array}$} & $6.1(1.0)$ & \multirow{3}{*}{$\begin{array}{l}.782 / .800 \\
.581 / .837\end{array}$} & $* * *$ \\
\hline How does ... meet your expectations (not at all/totally) ${ }^{\mathrm{b}}$ & $4.8(1.5)$ & & $5.6(1.2)$ & & $5.9(1.1)$ & & \multirow{2}{*}{$\begin{array}{l}* * * \\
* * *\end{array}$} \\
\hline $\begin{array}{l}\text { Think of an ideal town center/shopping mall. To what extent } \\
\text { does ... comes close to that? (not close/very close) }\end{array}$ & $4.1(1.7)$ & & $4.5(1.7)$ & & $5.1(1.7)$ & & \\
\hline \multicolumn{8}{|l|}{ Retention proneness $\left(\eta_{2}\right)$} \\
\hline You are willing to stay here ... as long as possible. ${ }^{c}$ & $4.8(2.7)$ & \multirow{3}{*}{$\begin{array}{l}.756 / .760 \\
.518 / .306\end{array}$} & $3.9(2.5)$ & \multirow{3}{*}{$\begin{array}{l}.749 / .765 \\
.530 / .345\end{array}$} & $3.4(2.5)$ & \multirow{3}{*}{$\begin{array}{l}.724 / .739 \\
.500 / .600\end{array}$} & $* * *$ \\
\hline You enjoy spending your time here in .... ${ }^{\text {c }}$ & $5.8(2.7)$ & & $4.9(2.7)$ & & $5.1(3.0)$ & & $* * *$ \\
\hline You are up to many things here in ... today. ${ }^{\mathrm{c}}$ & $5.3(3.0)$ & & $3.9(2.6)$ & & $3.5(2.5)$ & & $* * *$ \\
\hline \multicolumn{8}{|l|}{ Patronage intention $\left(\eta_{3}\right)$} \\
\hline $\begin{array}{l}\text { Would you recommend ... ot other persons (definitely } \\
\text { not/definitely yes) }\end{array}$ & $5.9(2.4)$ & \multirow{3}{*}{$\begin{array}{l}.765 / .793 \\
.574 / .290\end{array}$} & $7.2(2.2)$ & & $7.8(2.2)$ & \multirow{3}{*}{$\begin{array}{l}.786 / .803 \\
.577 / .842\end{array}$} & $* * *$ \\
\hline $\begin{array}{l}\text { How likely are you to go to ... again (very unlikely/very } \\
\text { likely) }\end{array}$ & $8.3(2.2)$ & & $8.9(1.8)$ & $\begin{array}{l}.763 / .782 \\
.547 / .516\end{array}$ & $8.8(1.8)$ & & $* *$ \\
\hline $\begin{array}{l}\text { How likely are you to go to ... again and buy somenthing (very } \\
\text { unlikely/very likely) }\end{array}$ & $8.1(2.3)$ & & 8.5 (1.9) & & $8.9(1.8)$ & & $* * *$ \\
\hline \multicolumn{8}{|c|}{ 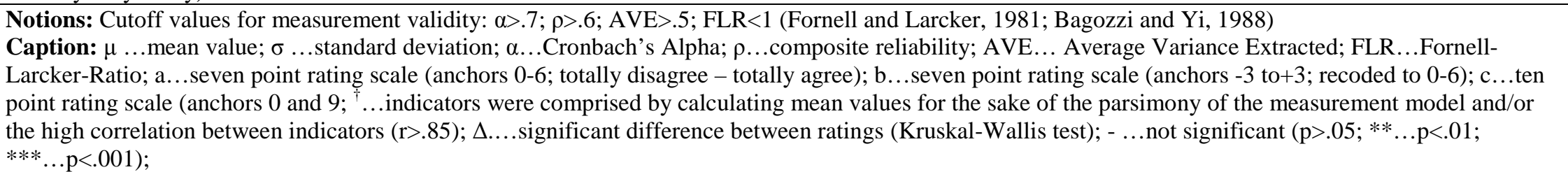 } \\
\hline
\end{tabular}

